\title{
Green synthesis, Antioxidant Potential and Hypoglycemic Effect of Silver Nanoparticles using Ethanolic Leaf Extract of Clausena anisata (Willd.) Hook. F. Ex Benth. of Rutaceae
}

\author{
Arsia Tarnam $\mathrm{Y}^{1}$, Nargis Begum $\mathrm{T}^{1}$, Muhammad Ilyas $\mathrm{MH}^{2}$, Shilu Mathew ${ }^{1}$ Archunan Govindaraju ${ }^{3}$ and \\ Ishtiaq Qadri ${ }^{*}$
}

\section{Arsia Tarnam $\mathrm{Y}^{1}$ Nargis Begum $T^{1}$, Muhammad llyas $\mathrm{MH}^{2}$, Shilu Mathew ${ }^{1}$ Archunan Govindaraju ${ }^{3}$ and Ishtiaq Qadri $^{4^{*}}$}

\section{${ }^{1} P G$ \& Research Department of Biotechnology, Jamal Mohamed College, Tiruchirappalli,INDIA. ${ }^{2} P G$ \& Research Department of Botany, Jamal Mohamed College, Tiruchirappalli, INDIA. \\ ${ }^{3}$ Department of Animal Science, Bharathidasan University Tiruchirappalli-620 024, INDIA. ${ }^{4}$ Division of Virology, Department of Biological Sciences, Faculty of Science, King Abdulaziz University, JEDDAH.}

\section{Correspondence}

Prof.Ishtiaq Qadri

Division of Virology, Department of Biological Sciences, Faculty of Science, King Abdulaziz University, Jeddah Jeddah,K.S.A

Mobile 00966500665783

Email: ishtiaqmq@gmail.com

DOI : 10.5530/pj.2016.6.8

Article Available online

http://www.phcogj.com/v8/i6

Copyright

(C) 2016 Phcog.Net. This is an open-

access article distributed under the terms of the Creative Commons Attribution 4.0 International license.

\begin{abstract}
The current study was conducted to examine the hypoglycemic effect of Silver Nano particles (SNPs) using ethanolic leaf extract of Clausena anisata (Willd.) Hook $f$. ex Benth. A cost effective and eco-friendly technique for the green synthesis of SNPs from $1 \mathrm{mM}$ $\mathrm{AgNO}_{3}$ solution through the leaf extract was carried out. The biosynthesized SNPs were characterized using UV spectro photometry, Field Emission Scanning Electron Microscopy (FESEM), X-ray Diffraction analysis (XRD), Energy Dispersive Spectroscopy (EDS) and Fourier transform infra-red (FTIR) spectrometry. DPPH assay was done to determine the antioxidant activity and for in vitro hypoglycemic activity glucose uptake by yeast cells, alpha-amylase inhibition assay, adsorption capacity and glucose diffusion assay was carried out. The SNPs of ethanol leaf extract were found to be spherical in shape and up to $60.67 \mathrm{~nm}$ average in size. They showed alpha-amylase inhibitory activity of $80.32 \%$ at $500 \mu \mathrm{g} / \mathrm{ml}$ and $\mathrm{IC}_{50} 100 \mu \mathrm{g} / \mathrm{ml}$. The glucose uptake by yeast cells was found to increase with an increase in concentration. The maximum glucose uptake was found to be $68.29 \%$ at $10 \mathrm{mM}$ concentration. The molar concentration of glucose was directly proportional to the glucose binding capacity of extracts. The rate of glucose diffusion across the membrane was found to increase from 30 to 180 minutes. The DPPH scavenging activity was found to be potent $(71.60 \%)$ at $500 \mu \mathrm{g} / \mathrm{ml}$. The hypoglycemic effect exhibited by the SNPs was revealed by simple in vitro model of yeast cells, mediated by glucose absorption, increasing glucose diffusion and glucose transport across the cell membrane.
\end{abstract}

\section{INTRODUCTION}

Type II Diabetes is a metabolic disorder in which either insulin hormone is not produced in sufficient quantities or the insulin produced is defective and cannot move the glucose into the cells. It is characterized by chronic hyperglycemia that is associated with micro and macro vascular complications that can lead to visual impairment, blindness, kidney disease, nerve damage, amputations, heart disease, and stroke. ${ }^{1}$ Glucose control (fasting blood sugar in diabetes - $126 \mathrm{mg} / \mathrm{dl}$ and above; random blood sugar in diabetes - $200 \mathrm{mg} / \mathrm{dl}$ and above) is the major target in the management of type II diabetes. Therefore, it is necessary to reduce hyperglycemia in order to decrease the onset and progression of micro vascular complications. ${ }^{2}$ There are several synthetic drugs like biguanides, sulfonylurea, Meglitinides, Thiazolidinediones, Alpha-Glucosidase Inhibitors, GLP-1 Inhibitors, Pramlintide and DPP-4 Inhibitors are available but due to their high cost and side effects, traditional treatment with plants having medicinal potential becomes an alternative option for health conscious and financially poor populations. ${ }^{3}$

Clausena anisata (Willd.) Hook f. ex Benth deciduous shrubs or small tree found in tropical and South Asia is used traditionally in treating a wide range of diseased conditions, which is indigenous in South Africa. As with other species of Rutaceae family, the leaves, fruits and stem bark are rich in aromatic essential oils. The dried leaves of this plant act as an arthropod repellent, ${ }^{4}$ like filling material for mattresses and pillows against lice, fleas and bedbugs, ${ }^{5}$ antiinflammatory and antifungal activity, ${ }^{6}$ antibacterial activity, ${ }^{7}$ diabetes (hypoglycemia), ${ }^{8}$ rheumatism and migraine headache, ${ }^{9}$ in management of epilepsy, ${ }^{10}$ for cough and in treatment of tuberculosis, ${ }^{11}$ it act as mosquito repellant against Anopheles arabiensis. ${ }^{12,13}$ The leaves or roots decoction are taken for gastrointestinal disorders, analgesia (headache, toothache) pneumonia and antipyretic, ${ }^{14}$ hypotension, venereal diseases, sinusitis and sore throat, as an anthelmintic and aphrodisiac, ${ }^{15}$ antioxidant and crushed leaves are used in treating wounds in domestic animals, ${ }^{16}$
Cite this article : Arsia Tarnam Y, Nargis Begum T, Muhammad llyas MH, Mathew S, Govindaraju A, Qadri I. Green synthesis, Antioxidant Potential and Hypoglycemic Effect of Silver Nanoparticles using Ethanolic Leaf Extract of Clausena anisata (Willd.) Hook. F. Ex Benth. of Rutaceae. Pharmacognosy Journal. 2016;8(6):565-575. 
as a tonic to cure breast pain in pregnant women, ${ }^{17}$ to control convulsions in infants and as a tonic to prevent rickets.

We report for the first time, the biosynthesis and characterization of SNPs generated by the reduction of $C$. anisata ethanolic leaf extract. The biologically synthesized nano particles were analyzed and tested for its antioxidant and hypoglycemic activity invitro.

\section{MATERIALS AND METHODS}

\section{Procurement of plant material}

Fresh leaves of C. anisata (Figure 1) were procured in the months of October to November (2013) from Manamettupatti of Viralimalai Taluk (Pudukottai District, Tamilnadu). The plant was identified by Dr. S. John Britto, Director, The Rapinat Herbarium and Centre for Molecular Systematics of St. Joseph's College, Tiruchirappalli - 620002 and authenticated as Clausena anisata (Willd.) Hookf. ex Benth. vouchered herbarium by specimen No: LB NSD 001.

\section{Preparation of plant extract and SNPs}

$10 \mathrm{~g}$ of shade dried leaf powder was macerated at $35^{\circ} \mathrm{C}$ to $37^{\circ} \mathrm{C}$; three to five times for $15-20 \mathrm{hrs}$ with $100 \mathrm{ml}$ of ethanol in an Erlenmeyer flask $(500 \mathrm{ml})$. Then the extract was centrifuged, filtered using Whatmann No. 1 filter paper and safely stored. The biosynthesis of SNP was carried out as outlined by the method. ${ }^{18}$

\section{Optimization and synthesis of SNPs}

$1 \mathrm{ml}, 3 \mathrm{ml}$ and $5 \mathrm{ml}$ of ethanolic leaf extracts were taken in a separate conical flask and to this $10 \mathrm{ml}$ of $1 \mathrm{mM} \mathrm{AgNO}_{3}$ solution was added with constant stirring and were exposed under different conditions like sunlight radiation, direct boiling, microwave irradiation (10s on, 10s off) to prevent overheating and aggregation of metals, UV irradiation and room temperature. The color change of the leaf extract was checked periodically and the color changes from green to dark brown indicate the synthesis of SNPs from the leaves.

\section{Production and recovery of SNPs}

For bulk production, $10 \mathrm{ml}$ of leaf extract in $100 \mathrm{ml}$ of $1 \mathrm{mM} \mathrm{AgNO}_{3}$ was prepared. After reduction, the extract consisting of SNPs was subjected to centrifugation at $10,000 \mathrm{rpm}$ for 20 minutes, and the supernatant was discarded. To the pellet, $0.1 \mathrm{ml}$ of toluene-water was added, air dried, lyophilized and stored for further characterization.

\section{CHARACTERIZATION STUDIES}

The biosynthesized SNPs were characterized by the following methods:

\section{Visual Observation}

A change of color from green to reddish brown was periodically noticed in the leaf extracts exposed to different conditions as illustrated earlier.

\section{UV Spectro photometric analysis}

The formation of SNPs was confirmed and was studied using the spectral analysis. The UV spectra of the biosynthesized SNPs were recorded using Lambda 35, Perkin Elmer Spectrophotometer by continuous scanning from $190 \mathrm{~nm}$ to $1100 \mathrm{~nm}$ and distilled water was used as the reference.

\section{Fourier Transform Infra Red Spectroscopy Analysis (FTIR)}

The functional groups in the biosynthesized SNPs were analyzed by FTIR spectroscopy. These measurements were carried using a Perkin Elmer spectrum RX I FTIR instrument with a wavelength range of $4000 \mathrm{~cm}^{-1}$ to $400 \mathrm{~cm}^{-1}$. The results were compared for as hift in functional peaks.

\section{Field Emission Scanning Electron Microscopy (FESEM)}

FESEM was used to characterize the mean particle size, morphology of the SNPs. A small drop of biosynthesized SNPs solution was placed on a glass slide and allowed to dry. The samples were analyzed by using FEI Quanta 200 FEG machine at a low vacuum in the range $10-20 \mathrm{Kv}$.

\section{Energy Dispersive Spectroscopy (EDS)}

The elemental composition of the synthesized SNPs was analyzed with energy dispersive spectroscopy coupled to scanning electron microscope.

\section{X-ray Diffraction Analysis (XRD)}

The structure and composition of SNP were studied by XRD (XPERTPRO Machine). The data was collected in the $2 \theta$ range.

\section{Determination of antioxidant activity (DPPH assay)}

The antioxidant activity of the SNPs was evaluated by DPPH radical scavenging assay. ${ }^{19} \mathrm{SNPs}$ of different concentration ranging from $100 \mu \mathrm{g} / \mathrm{ml}$ $500 \mu \mathrm{g} / \mathrm{ml}$ was prepared. To this, DPPH at a concentration of $0.1 \mathrm{mM}$ was added and incubated at room temperature for 30minutes. The absorbance was recorded at $517 \mathrm{~nm}$. The control sample was carried out without adding leaf extract. Ascorbic acid was used as a standard control.

\section{In Vitro Hypoglycemic Activity}

Alpha - amylase inhibition assay

The alpha-amylase inhibitory activity was carried out using acarbose as the reference compound ${ }^{20,21}$ based on the spectro photometric assay. The SNPs at a concentration of $100-500 \mu \mathrm{g} / \mathrm{ml}$ was prepared by dissolving in DMSO. $3.246 \mathrm{mg}$ of $\alpha$-amylase $(0.5 \mathrm{U} / \mathrm{ml}$ ) (EC 3.2.1.1) was dissolved in $100 \mathrm{ml}$ of $20 \mathrm{mM}$ phosphate buffer $\left(\mathrm{p}^{\mathrm{H}} 6.7\right)$ containing $6.5 \mathrm{mM}$ sodium chloride. Seven duplicate test samples including the blank and control were prepared. In each sample, $250 \mu$ l of the enzyme was added with $100 \mu \mathrm{l}$ of SNP extracts of different concentrations except blank and were incubated in a water bath at $37^{\circ} \mathrm{C}$ for 20 minutes with constant stirring in a vortex. After incubation, $250 \mu \mathrm{l}$ of starch $(0.5 \% \mathrm{w} / \mathrm{v}$ starch dissolved in $20 \mathrm{mM}$ phosphate buffer, $\mathrm{p}^{\mathrm{H}} 6.7$ ) was transferred into each sample in the test tube to initiate the reaction. It was again incubated at $37^{\circ} \mathrm{C}$ for 15 minutes after vortexing. DNS reagent of $2 \mathrm{ml}$ was added and stirred in a vortex. Later it was boiled in a water bath at $100^{\circ} \mathrm{C}$ for 10 minutes, thereafter the mixture was cooled down and the absorbance was measured at 540nm and control sample was carried out without adding the leaf extract.

\section{Glucose uptake by yeast cells}

Commercial baker's yeast was prepared in distilled water ${ }^{22}$ by repeated centrifugation at 21000rpm for 5 mins until the super natant was clear. The $10 \%(\mathrm{v} / \mathrm{v})$ concentration of yeast suspension was prepared in distilled water. SNP extracts at concentration of $100 \mu \mathrm{g}-2 \mathrm{mg}$ were added separately to $1 \mathrm{ml}$ of glucose solution $(5,10,25 \mathrm{~mm} \mathrm{ol} / \mathrm{L})$ and incubated for 10 minutes at $37^{\circ} \mathrm{C}$. To this, $100 \mu \mathrm{L}$ of yeast suspension was added to start the reaction and vortexed. Then it was incubated at $37^{\circ} \mathrm{C}$ for 60 minutes. After $60 \mathrm{~min}$, at $3800 \mathrm{r} / \mathrm{min}$ for $5 \mathrm{~min}$ the tubes were centrifuged and the glucose present in the supernatant was estimated at $540 \mathrm{~nm} .^{23}$

\section{Glucose Diffusion Assay}

$1 \mathrm{~mL}$ of a glucose solution at a concentration of $25 \mathrm{mmol} / \mathrm{L}$ was prepared by dissolving in $0.15 \mathrm{M} \mathrm{NaCl}^{24}$ and $1 \%$ of SNPs were dialyzed in two separate dialysis bags for control and test sample. Then the dialysis membrane was tied at both ends and immersed in a separate beaker containing $10 \mathrm{ml}$ of distilled water and $40 \mathrm{ml} 0.15 \mathrm{M} \mathrm{NaCl}$. For control, SNP extract was not added. The beakers were incubated at room temperature. The glucose 
content in the dialysate was determined at $30,60,120$ and 180 min by DNS method. ${ }^{25}$

\section{Dinitrosalicylic colorimetric method (DNS)}

After incubation, $250 \mu \mathrm{l}$ of the starch $(0.5 \% \mathrm{w} / \mathrm{v}$ of starch was dissolved in $20 \mathrm{mM}$ phosphate buffer $\left.\left(\mathrm{p}^{\mathrm{H}} 6.7\right)\right)$ was transferred into each test tube carrying glucose content of dialysate at 30,60, 120 and 180 mins. The vortexed mixture was incubated at $37^{\circ} \mathrm{C}$ for $15 \mathrm{mins}$. DNS reagent of $2 \mathrm{ml}$ was added, stirred in a vortex and boiled in a water bath at $100^{\circ} \mathrm{C}$ for 10 mins. The mixture was cooled and the absorbance was measured at $540 \mathrm{~nm}$.

\section{Glucose Adsorption Capacity}

SNP at a concentration of $1 \%$ was added to $25 \mathrm{~mL}$ of 5,10 , and $25 \mathrm{~mm}$ $\mathrm{ol} / \mathrm{L}$ glucose solution in four separate experiments. The content was vortexed and incubated in water bath at $37^{\circ} \mathrm{C}$ for $6 \mathrm{hrs}$ and centrifuged at $4800 \mathrm{rpm} / \mathrm{mins}$ for $20 \mathrm{mins}$. The glucose content in the supernatant was determined at $540 \mathrm{~nm}$.

\section{Statistical analysis}

The results were expressed as the mean \pm standard deviation from three independent experiments with triplicates. One way analysis of variance (ANOVA) was performed followed by Tukey's test. $\mathrm{P}<0.05$ was considered statistically significant.

\section{RESULTS AND DISCUSSION}

Among various concentration and methods used, $1 \mathrm{ml}$ of extract exposed under sunlight irradiation was found to be very effective and showed the maximum synthesis of nano particles. In this study, it was observed that there was visible color change when silver nitrate was added to the leaf extract. Initially, the leaf extract was green in color and after the addition of silver nitrate; it was turned into brown in color (Figure 2).The ethanolic leaf extract of C. anisata reduced silver ions into SNP was evidenced by the visual color change. This indicated the formation of SNPs due to excitation of surface Plasmon vibration in silver nano particles.

\section{UV - Vis spectral analysis of SNPs}

The SNP leaf extract was scanned in the wavelength ranging from 190nm-1100nm by using UV spectrophotometer (model: Lambda 35). The profile showed the peaks at $488.99 \mathrm{~nm}$ (Figure 3 ) with the absorption 0.86693 and it corresponds to the surface plasmon resonance of SNPs. This is in accordance with the earlier findings. ${ }^{27}$ Depending on the shape, size, aggregation nature and the adjacent dielectric medium ${ }^{28}$ the absorption band of metal nano particles is conquered by the SPR.

\section{FTIR Spectrum}

The bio molecules responsible for capping and efficient stabilization of the SNPs synthesized by leaf extract was identified by FTIR measurements and were similar to the earlier report. ${ }^{29}$ The SNP plant extract was passed into the FTIR (Model: Perkin Elmer Spectrophotometer system), based on its peak ratio the functional groups of the components were separated. The identification was based on the FTIR peaks attributed to stretching and bending vibrations (Figure 4). Nearly eight areas were identified and produced in Table 1.

\section{FESEM image analysis}

The size and shape of the SNP formed were analyzed by FESEM and the images are shown. the hydrogen bond and electro static interactions between the bio-organic capping molecules bound to the SNPs was responsible for the image. The SNPs were not in direct contact that may be due to the stabilization of the nano particles by a capping agent. The
Table 1: FTIR spectral peak values and functional groups obtained for the SNP leaf extract of $C$. anisata

\begin{tabular}{|c|c|c|c|}
\hline S.No & Peak Value $\left(\mathrm{cm}^{-1}\right)$ & Bond Type & $\begin{array}{c}\text { Functional } \\
\text { Groups }\end{array}$ \\
\hline 1 & 667.22 & $-\mathrm{C} \equiv \mathrm{C}-\mathrm{H}$ & Alkynes \\
\hline 2 & 1015.41 & C-O Stretch & Alcohol, ester, ether \\
\hline 3 & 1360.46 & $\mathrm{~N}-\mathrm{O}$ symmetric stretch & Nitro compounds \\
\hline 4 & 1631.77 & $\mathrm{~N}-\mathrm{H}$ bend & Primary amine \\
\hline 5 & 2083.51 & $-\mathrm{C} \equiv \mathrm{C}-$ Stretch & Alkynes \\
\hline 6 & 2833.19 & $\mathrm{RCO}_{2} \mathrm{H}$ & Carboxylic acid \\
\hline 7 & 3432.71 & $\mathrm{O}-\mathrm{H}$ stretch/ H-bonded & Phenol, alcohol \\
\hline 8 & 3464.31 & O-H stretch/ H-bonded & Phenol, alcohol \\
\hline
\end{tabular}

larger silver particles may be due to the aggregation of the smaller ones. ${ }^{30}$ Synthesized SNPs showed spherical form and with a size distribution ranging from 13 to $61 \mathrm{~nm}$. The average size was found to be $60.67 \mathrm{~nm}$ (Figure 5).

\section{EDS Analysis}

The percentage of SNPs in the sample was analyzed by EDS. For this, the synthesized SNPs was characterized by using FEI Quanta 200 FEG HR-SEM equipped with EDAX instrument. The EDS spectra showed the different types of elements like Carbon (18.97\%), Chlorine (13.43\%), Oxygen (9.61\%), Copper $(2.76 \%)$ and Silver $(55.24 \%)$ present in the sample (Figure 6).

\section{XRD Characterization}

The XRD spectra were used to confirm the crystalline nature of the SNPs. The X-ray diffraction pattern of SNP was confirmed by the characteristic peak observed in XRD image. Four prominent peaks were observed at $2 \theta=31.85^{\circ}, 44.0^{\circ}, 64.2^{\circ}$, and $77.2^{\circ}$, (Figure 7) which corresponded to (111), (200), (220) and (311) respectively. The diffraction pattern inferred that the synthesized SNPs possessed nano-dimensional state. ${ }^{27}$

\section{Alpha- Amylase inhibition assay}

The glucose obtained from the indigestible carbohydrate food which contains starch is readily absorbed from the gastrointestinal tract into the blood stream after the hydrolysis of glycosidic bonds by the enzyme $a$-amylase. In diabetics, the inhibition of this enzyme reduced the high postprandial blood glucose level. In the present study, an in vitro alphaamylase inhibition model was used to screen the SNPs of C. anisata to evaluate the hypoglycemic effects. The alpha-amylase inhibitors obstruct the absorption and the digestion of carbohydrates. ${ }^{31}$ Acarbose, a synthetic alpha-amylase inhibitor delays the digestion of carbohydrates and inhibits the action of pancreatic amylase in the break down of starch, which leads to side effects such as abdominal pain, diarrhea and soft faeces in the colon. The SNPs of $C$. anisata inhibited the alpha amylase with $\mathrm{IC}_{50}$ value at $100 \mu \mathrm{g} / \mathrm{ml}$ similar to the principle as that of Acarbose. The maximum inhibition of $80.32 \%$ was found to be at $500 \mu \mathrm{g} / \mathrm{ml}$ when compared to standard $85.24 \%$ (Figure 8 ).

\section{Glucose uptake by yeast cells}

Inhibition of glucose uptake in $5 \mathrm{mM}, 10 \mathrm{mM}$, and $25 \mathrm{mM}$ glucose concentration: The rate of glucose transport across the yeast cell membrane was studied and SNP leaf showed a percentage inhibition of 50 while Acarbose showed a percentage inhibition of 62.82 at a concentration of $2000 \mu \mathrm{g} / \mathrm{ml}$ (Figure 9) for $5 \mathrm{mM}$.The graphical representation of the inhibition of glucose uptake in $10 \mathrm{mM}$ glucose concentration was presented (Figure 10). It showed a percentage inhibition of 68.29 while 


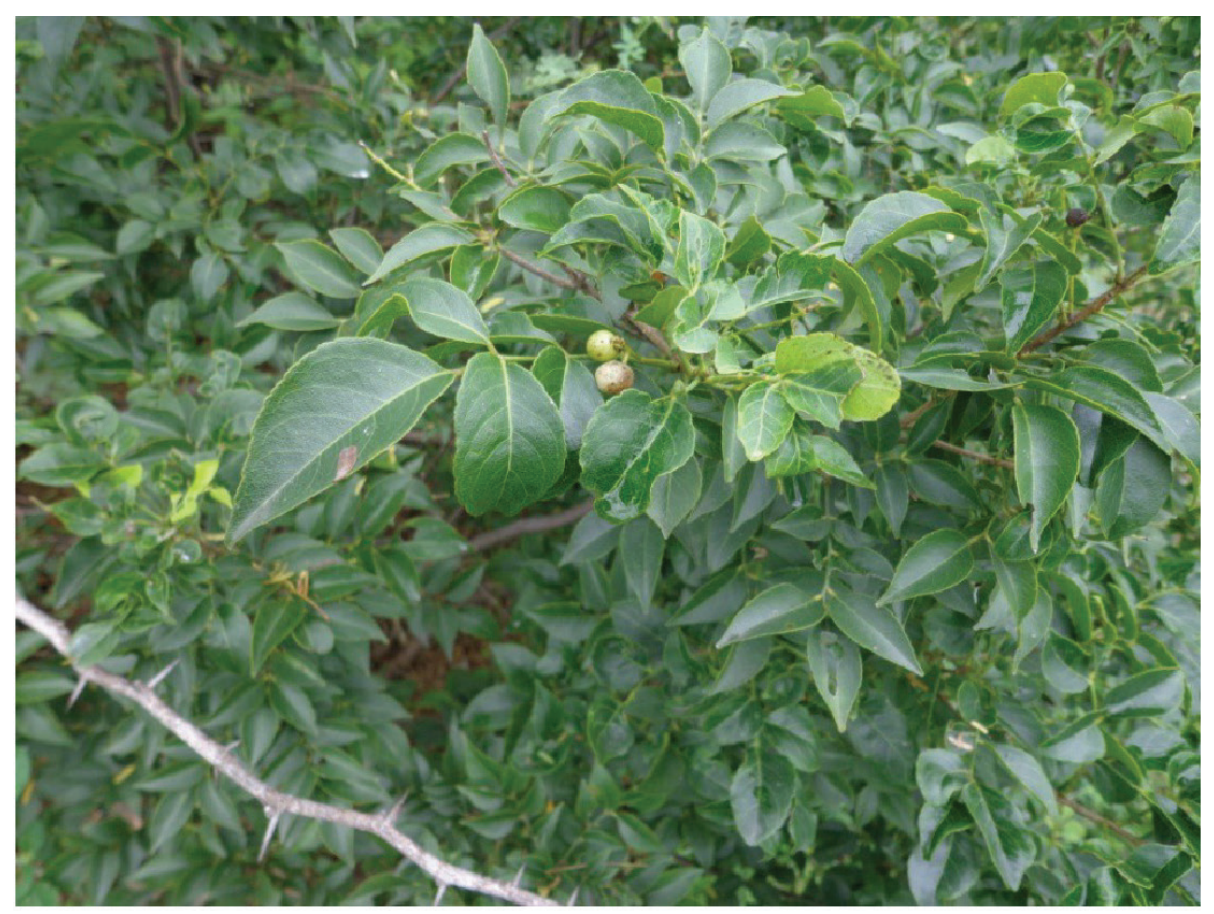

Figure 1: Leaves of Clausena anisata (Willd.) Hook. f. ex Benth. from Manamettupatti, Viralimalai Taluk (Pudukottai District, Tamilnadu)

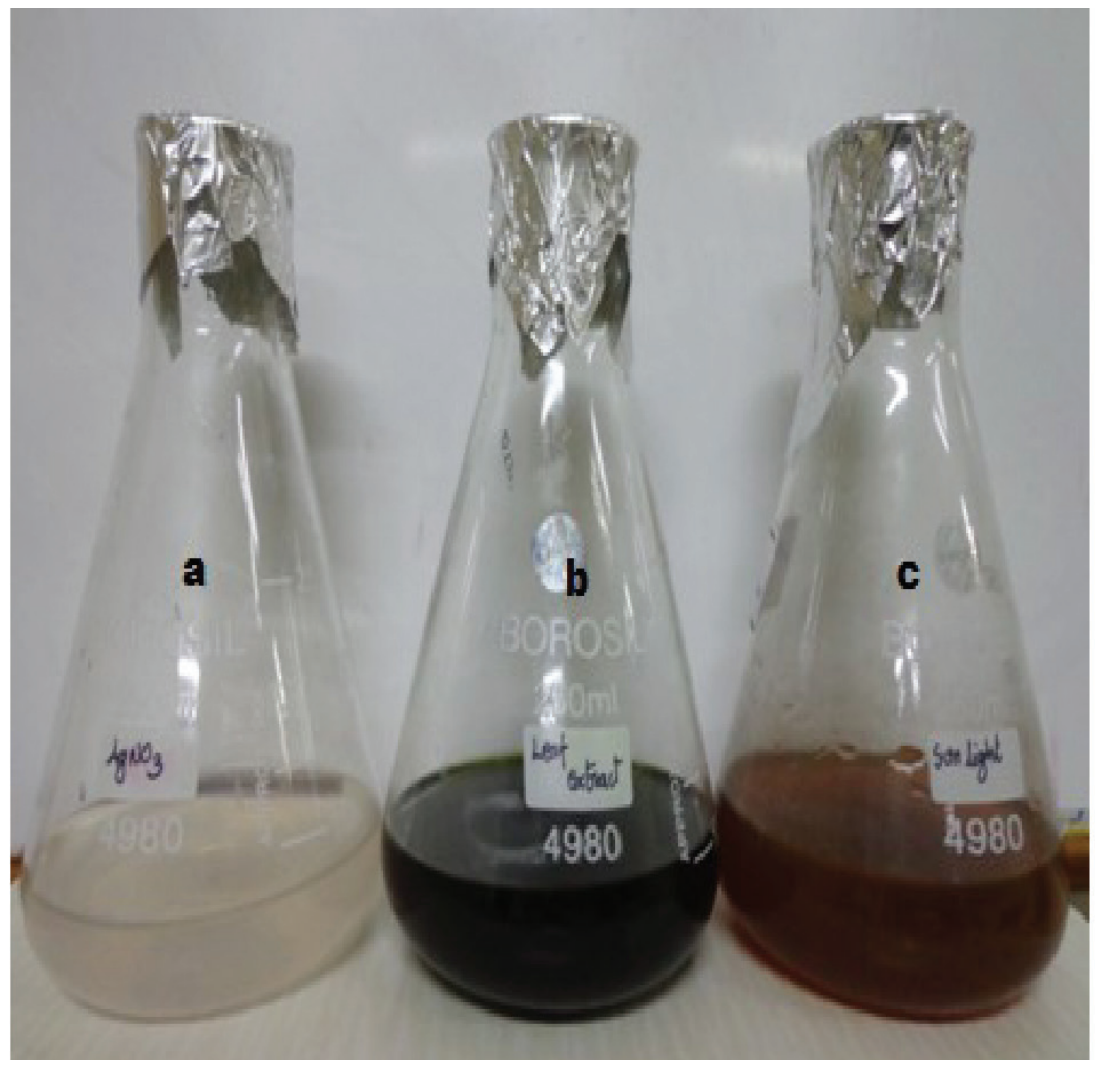

Figure 2: Synthesis of SNP a) $1 \mathrm{mM} \mathrm{AgNO3} \mathrm{b)} \mathrm{C.} \mathrm{anisata} \mathrm{ethanolic} \mathrm{leaf} \mathrm{extract} \mathrm{c)} \mathrm{Visible} \mathrm{color} \mathrm{change} \mathrm{from} \mathrm{green} \mathrm{to} \mathrm{brown} \mathrm{under}$ sunlightx 


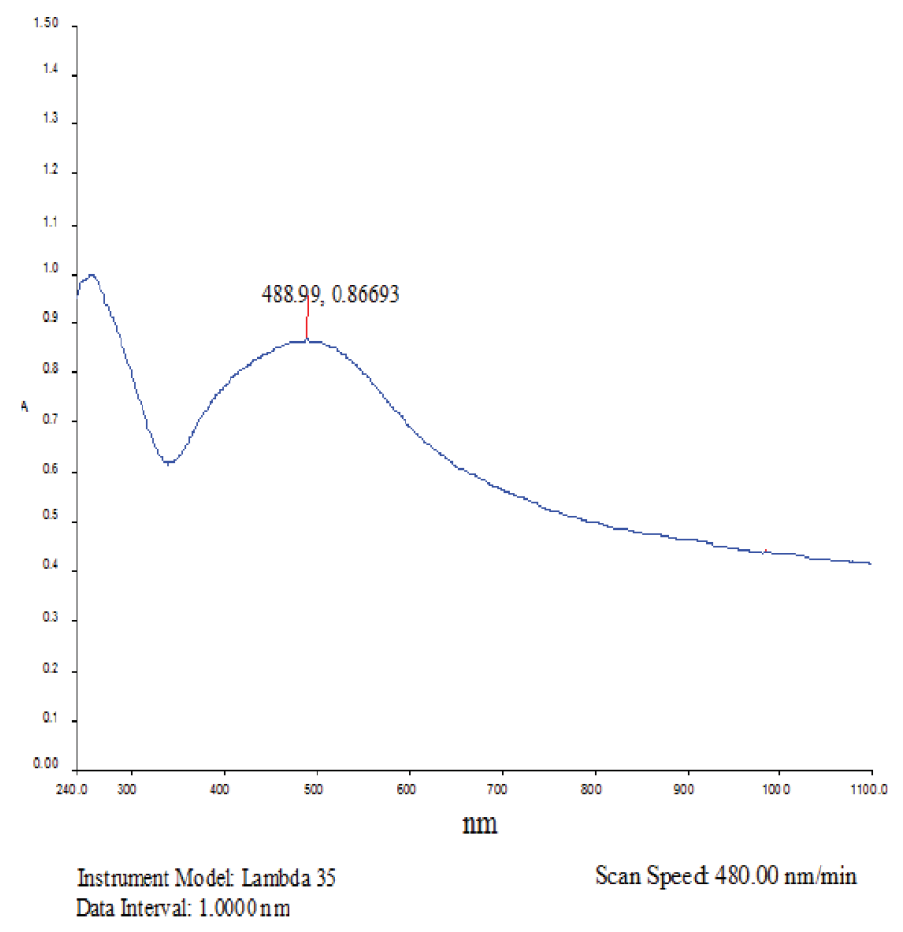

Figure 3: UV-Vis Spectra of synthesized SNP from ethanolic C. anisata leaf extract

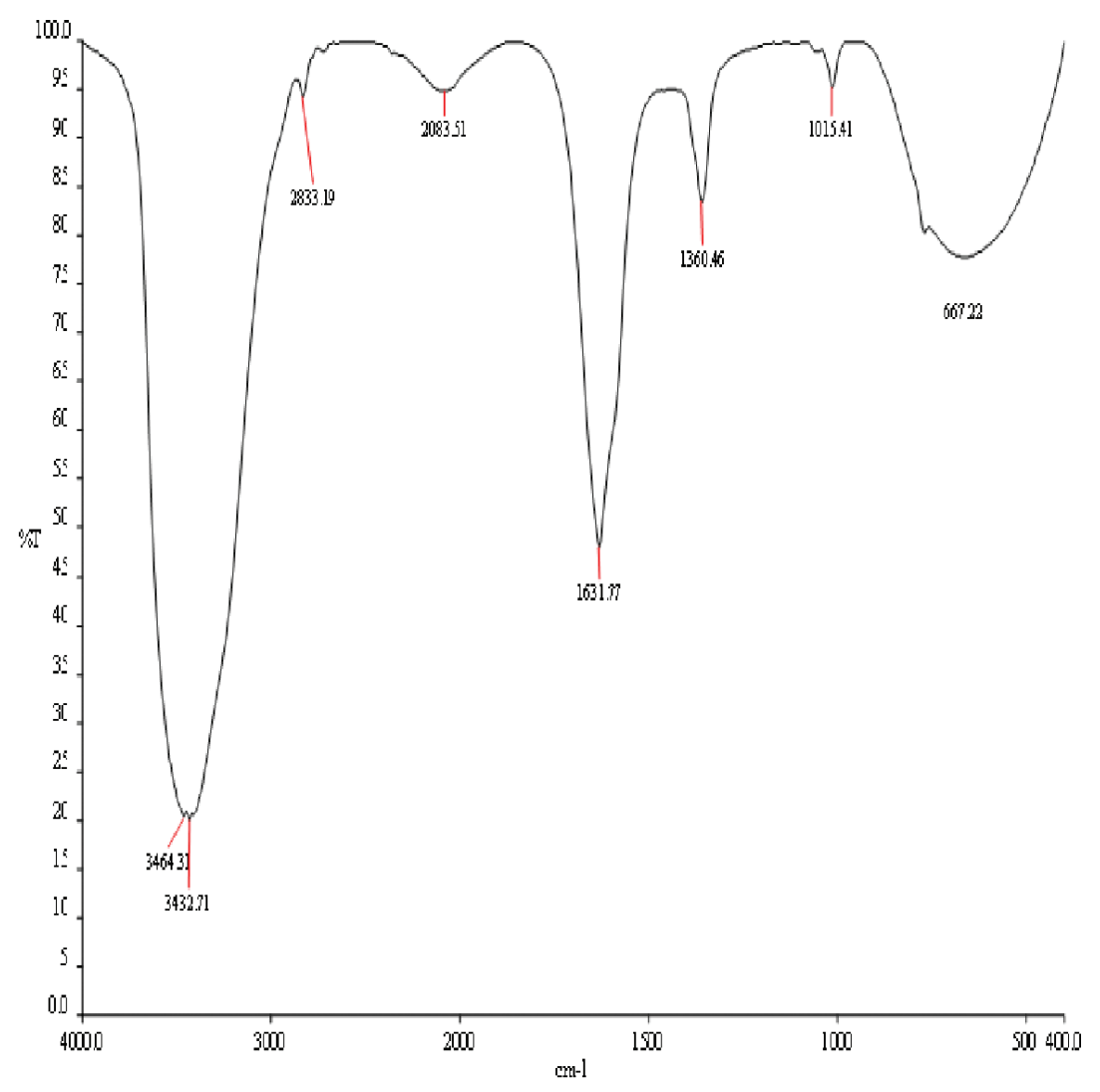

Figure 4: FTIR Spectrum of synthesized SNP from ethanolic C. anisata leaf extract 


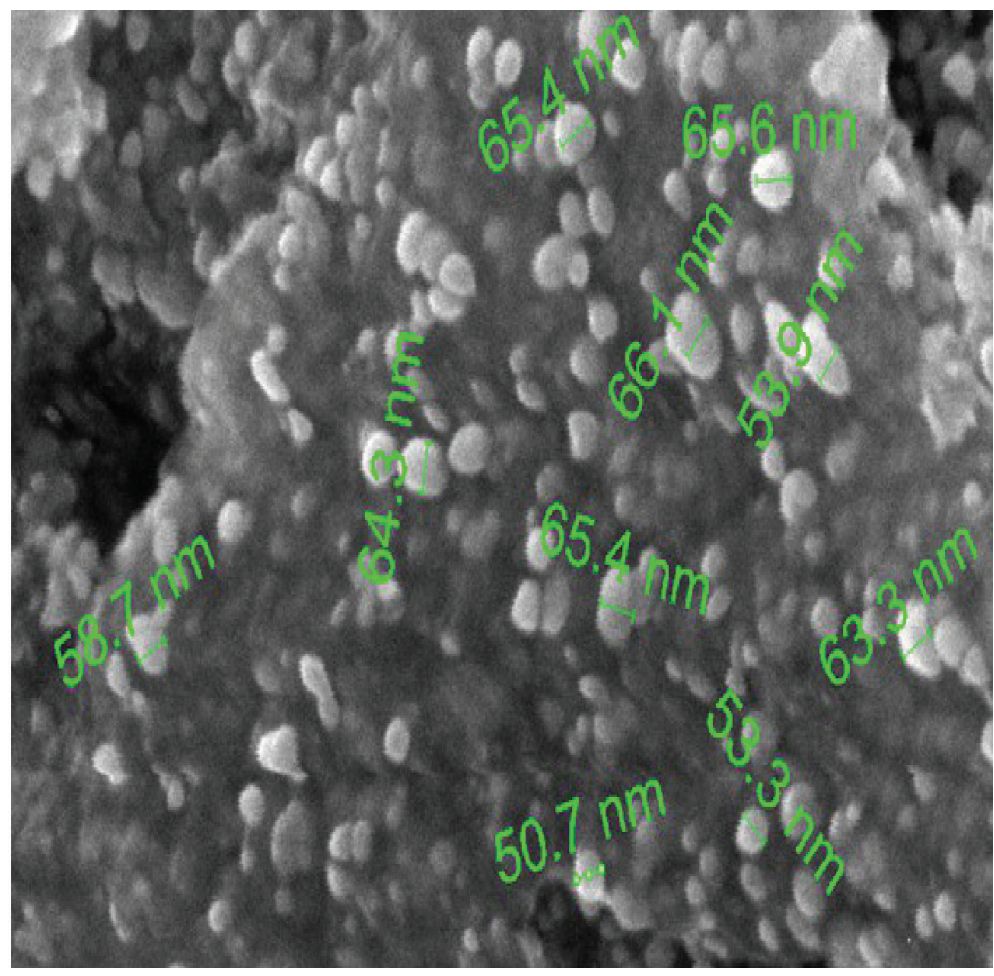

Figure 5: SEM image of synthesized SNP from ethanolic C. anisata leaf extract

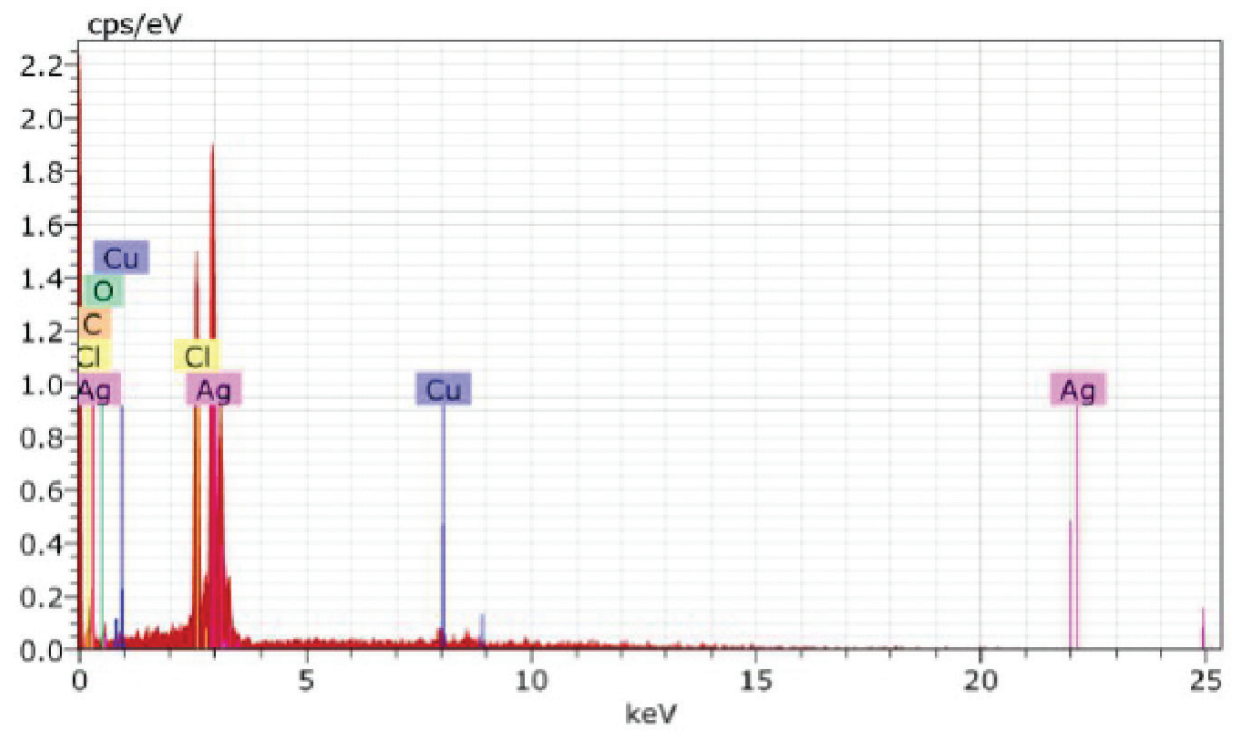

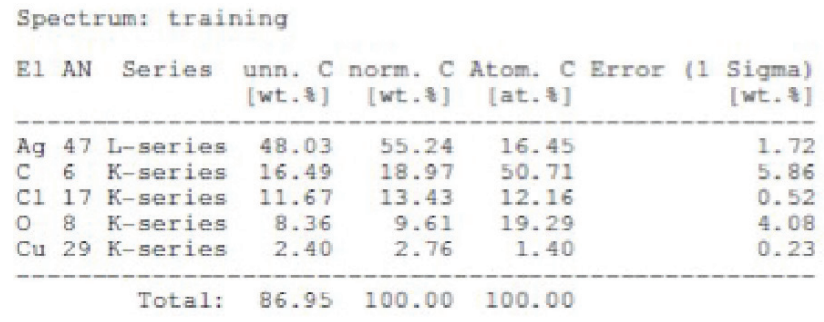

Figure 6: EDX plot of synthesized SNP from ethanolic C. anisata leaf extract 


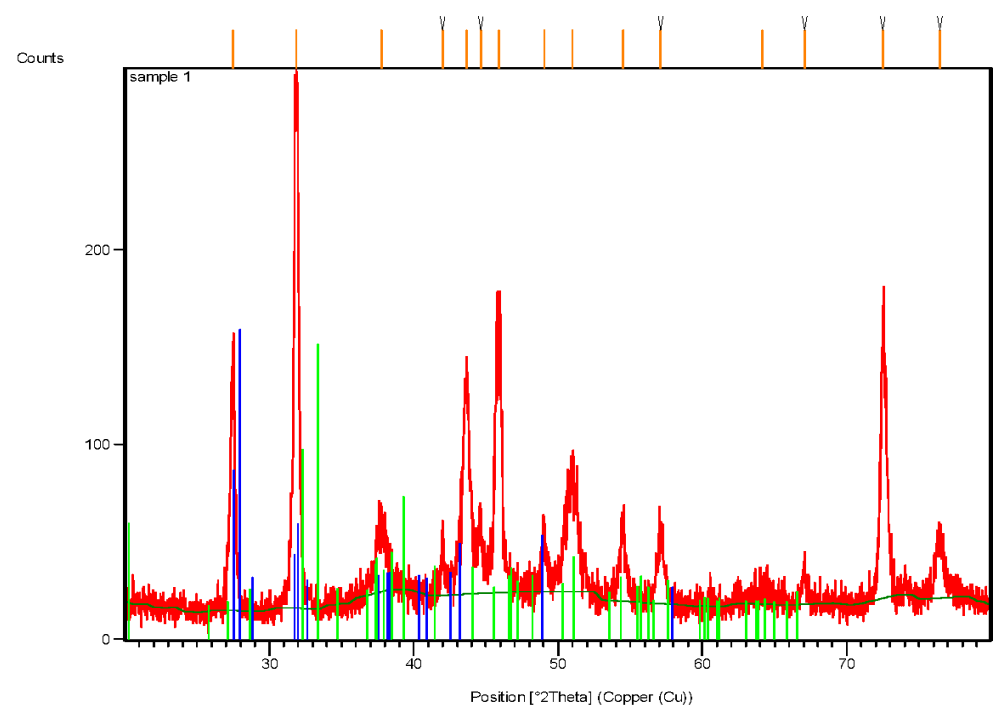

Figure 7: XRD pattern of synthesized SNP from ethanolic C. anisata leaf extract

Inhibition of a-am ylase enzym e Assay of Clansena anisata SNP Extract

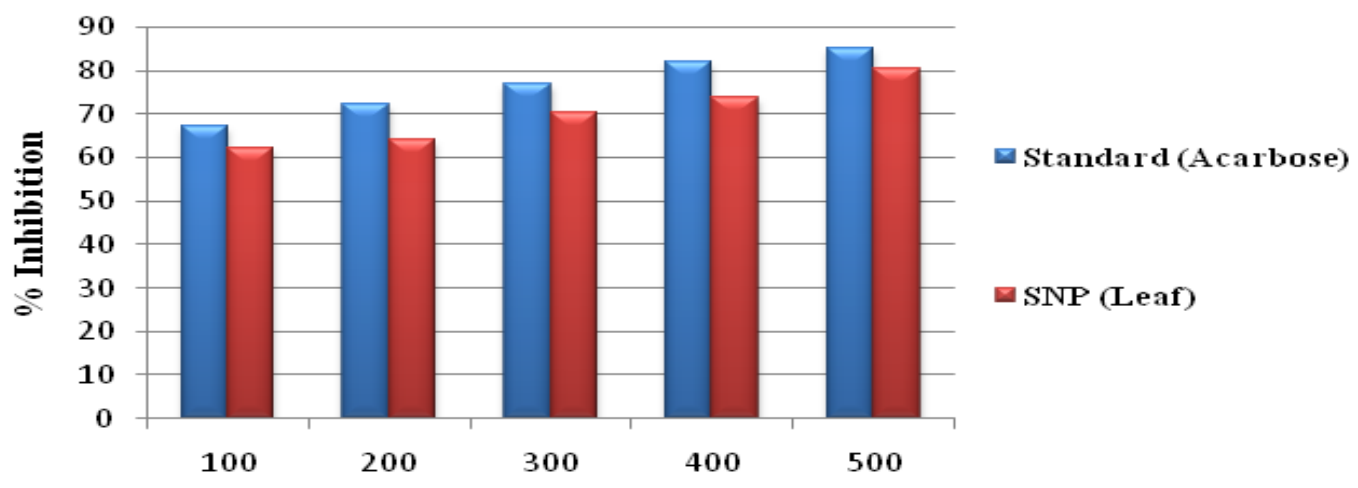

Concentration $\mu \mathrm{g} / \mathrm{m} \mathbf{l}$

Figure 8: Alpha amylase inhibitory activity of synthesized SNP from ethanolic C. anisata leaf extract

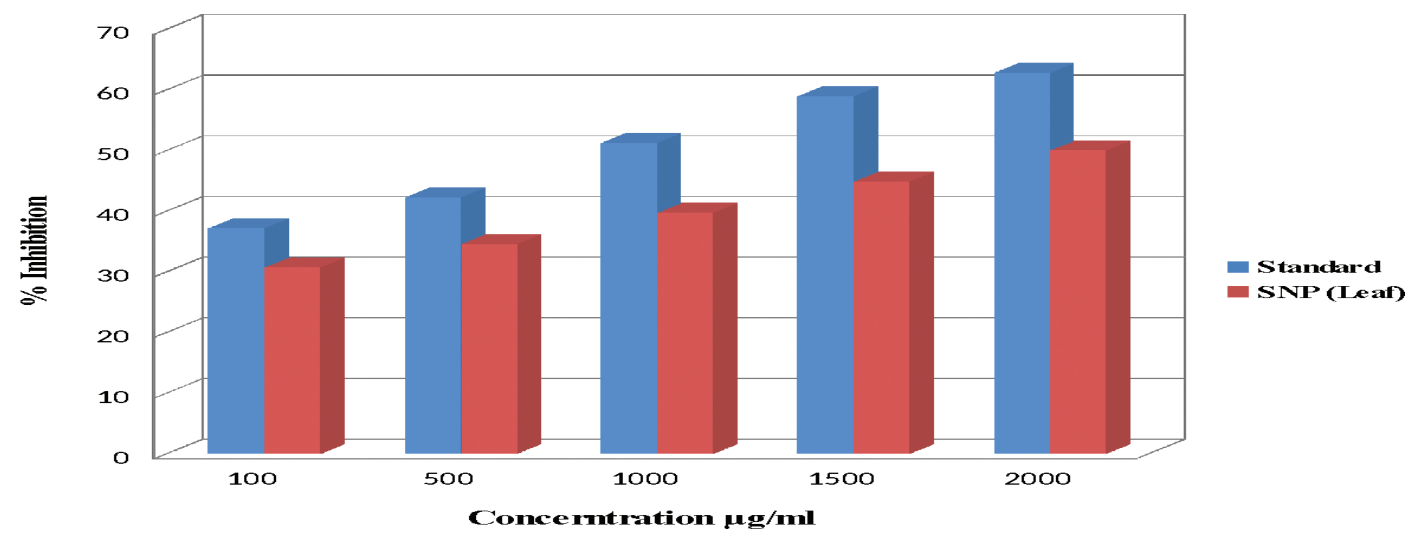

Figure 9: Effect of synthesized SNP from ethanolic C. anisata leaf extract on the uptake of glucose by yeast cells at $5 \mathrm{mM}$ concentration 


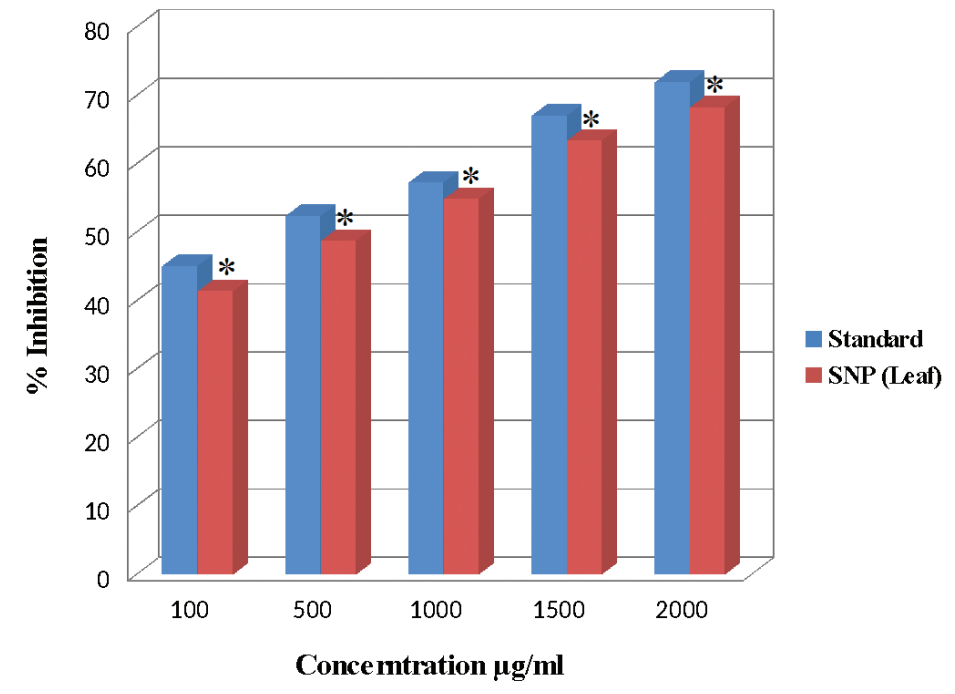

Figure 10: Effect of synthesized SNP from ethanolic C. anisata leaf extract on the uptake of glucose by yeast cells at $10 \mathrm{mM}$ concentration

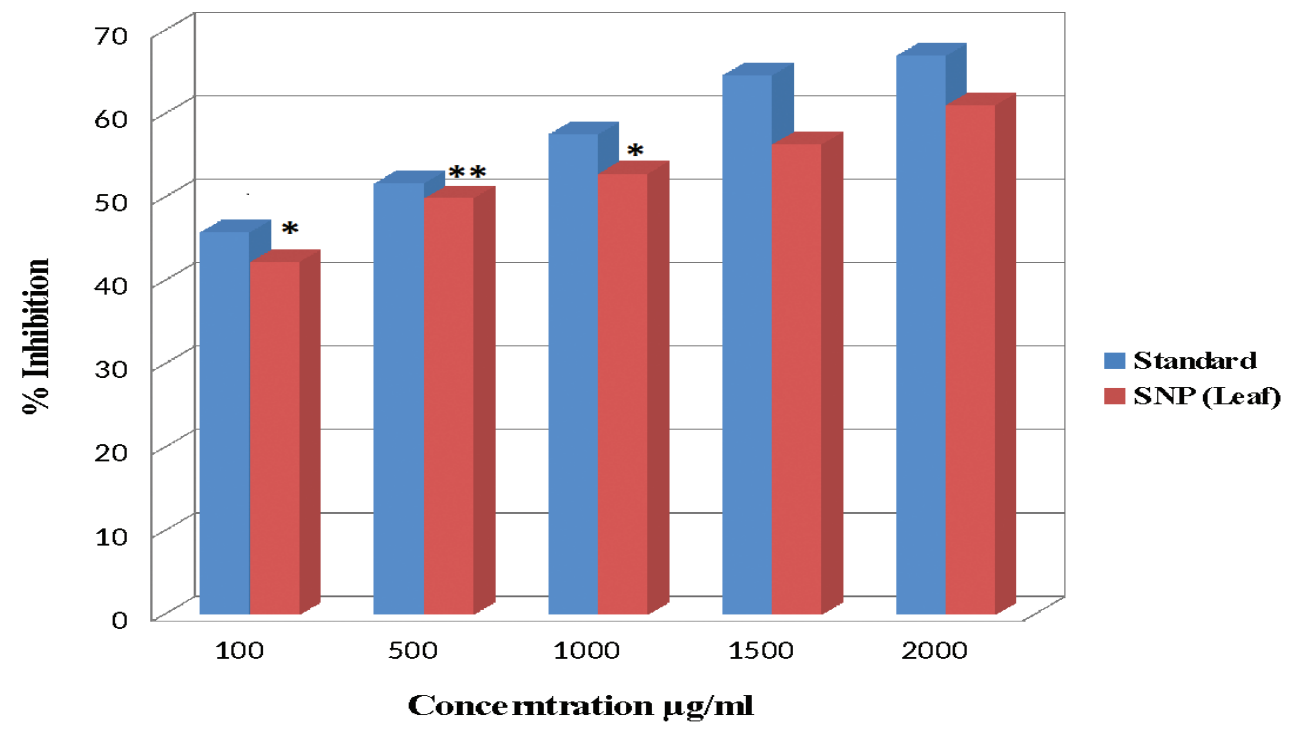

Figure 11: Effect of synthesized SNP from ethanolic C. anisata leaf extract on the uptake of glucose by yeast cells at $25 \mathrm{mM}$ concentration

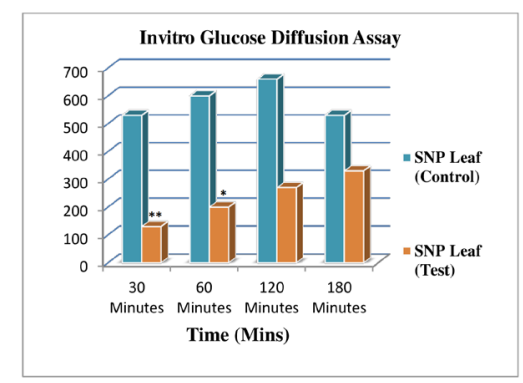

Figure 12: Effect of synthesized SNP from ethanolic C. anisata leaf extract on invitro glucose diffusion 


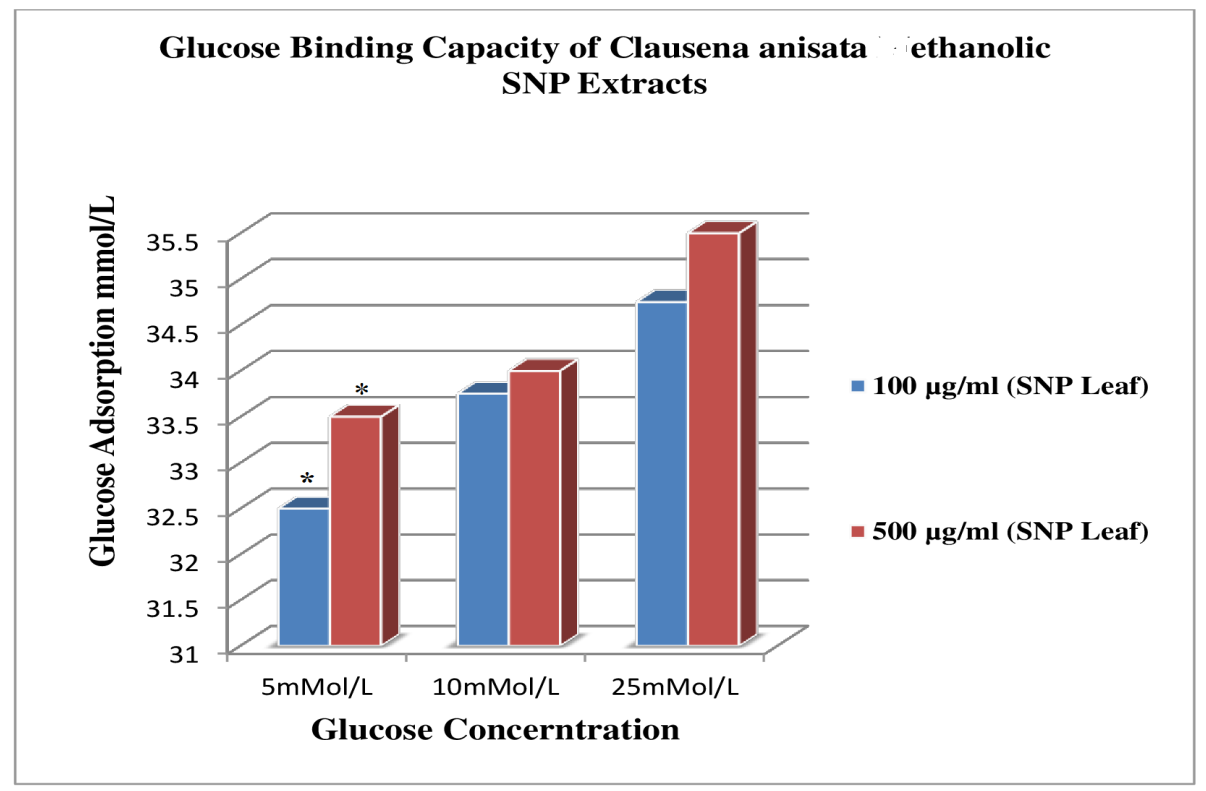

Figure 13: Invitro glucose binding capacity of synthesized SNP from ethanolic C. anisata leaf

\section{DPPH free Radical Scavenging Activity of Clausena anisata SNP Ethanolic extract}

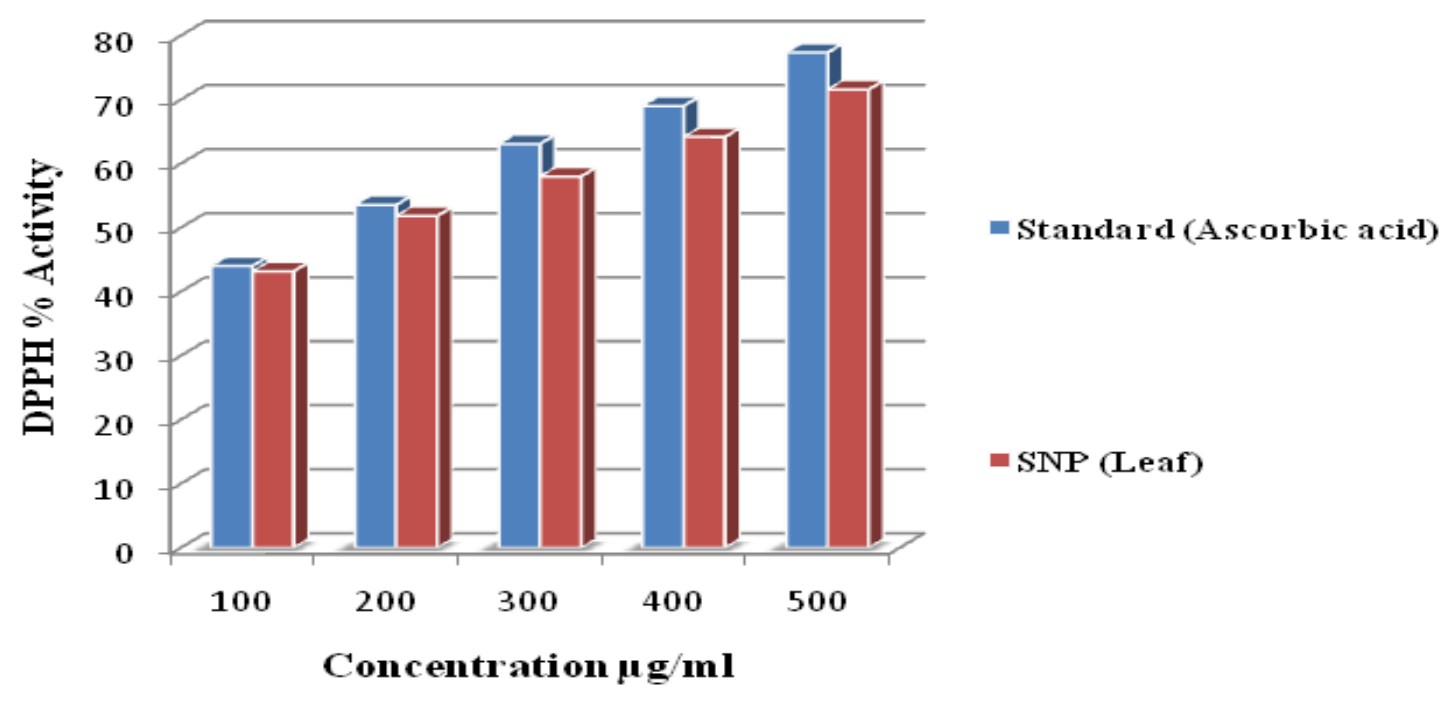

Figure 14: DPPH free radical scavenging activity of synthesized SNP from ethanolic C. anisata leaf 
A carbose showed a percentage inhibition of 71.95 at $2000 \mu \mathrm{g} / \mathrm{ml}$. The graphical representation of the inhibition of glucose uptake in $25 \mathrm{mM}$ glucose concentration was presented. It showed a percentage inhibition of 61.17 while A carbose showed a percentage inhibition of 67.05 at a concentration of $2000 \mu \mathrm{g} / \mathrm{ml}$ (Figure 11).

The glucose uptake in the SNP extract was found to increase in a dosedependent manner. The amount of glucose remaining in the medium was estimated, which served as a marker for the glucose uptake by the yeast cells. And it was found to be linear in $5 \mathrm{mM}, 10 \mathrm{mM}$, and $25 \mathrm{mM}$ glucose concentrations. From the results, it was clear that like standard SNPs had greater efficiency in increasing the glucose uptake by yeast cells in $5 \mathrm{mM}, 10 \mathrm{mM}$ and $25 \mathrm{mM}$ glucose concentrations. ${ }^{32}$

\section{Glucose Diffusion Assay}

Most efficient plants phytoconstituents have antihyperglycemic behaviors to increase glucose transport and metabolism in muscle and to stimulate insulin secretion. ${ }^{33}$ Glucose concentrations inside the dialysis tubing in the absence or presence of SNPs leaf extract were inversely related to the glucose concentrations in the external solution. In control, the glucose movement out of dialysis had reached a plateau with a mean glucose concentration in the external solution. This confirms that the SNPs of C. anisata signified an inhibitory potential of glucose diffusion. GDRI (\%) increased with decreasing leaf extract concentration. SNP was found to exhibited greater GDRI percent of 75.47, 66.66, 59.09, 37.73 at 30, 60, 120 and 180 minutes respectively (Figure 12).

\section{Glucose Adsorption Capacity}

In the presence of different levels of glucose, the SNP showed the high capacity of glucose adsorption. The glucose adsorption rate was found to persist from higher level to even low level of glucose present in the solution. As the concentration of glucose increased, the glucose adsorption capacity of SNP leaf extract also increased at a rate of $34.75 \mathrm{mmol}$ for $100 \mu \mathrm{g} / \mathrm{ml}$ in $25 \mathrm{mM}$ concentration of glucose and $35.5 \mathrm{mmol}$ for $500 \mu \mathrm{g} / \mathrm{ml}$ in $25 \mathrm{mM}$ concentration of glucose (Figure 13).

\section{Determination of antioxidant activity (DPPH assay)}

The one of the most widely used methods for screening antioxidant activity of plant extract is DPPH assay. The stable free radical was used to determine antioxidant activity of natural compounds. ${ }^{34}$ This assay detected the antioxidant activity of SNP extract and compared with the standard, which showed the $\mathrm{IC}_{50}$ values for SNP and ascorbic acid as $200 \mu \mathrm{g} / \mathrm{ml}$. The SNPs showed $71.60 \%$ inhibition at $500 \mu \mathrm{g} / \mathrm{ml}$ when compared with standard showed $77.38 \%$ inhibition at $500 \mu \mathrm{g} / \mathrm{ml}$ (Figure 14).

\section{CONCLUSION}

The results of the present study made on Clausena anisata to study the green synthesis, antioxidant potential and hypoglycemic effect of silver nano particles using ethanolic leaf extract revealed that the green synthesized SNPs showed antioxidant potential and the maximum in vitro hypoglycemic activity intervened by decreasing the glucose diffusion rate, increasing the glucose adsorption rate and by glucose transport across the cell membrane. Furthermore, to date no such study has been conducted to evaluate the hypoglycemic property of these SNP extract in this plant. However, these results should be confirmed by in vivo models, which is currently underway to confirm these observations for their effective utilization as therapeutic agents.

\section{ACKNOWLEDGEMENT}

We would like to thank Department of Biotechnology, Jamal Mohamed College, Tiruchirappalli, Tamilnadu and King Fahd Medical Research
Centre, Jeddah, K.S.A. for their support and Reviewers for careful proofreading and critical review of this manuscript.

\section{CONFLICT OF INTEREST}

All authors disclose no conflict of interest.

\section{REFERENCES}

1. Loghmani E. (2005) Diabetes Mellitis: Type 1 and Type 2. Guidelines for Adolescent Nutrition Services. 2005;167-182.

2. Inzucchi SE, Bergenstal RM, Buse JB et al. Management of Hyperglycemia in Type 2 Diabetes. Diabetes Care. 2015;38:140-9.http://dx.doi.org/10.2337/dc142441; PMid:25538310.

3. Yessoufou A, Gbenou J, Grissa O et al. Anti-hyperglycemic effects of three medicinal plants in diabetic pregnancy: modulation of T cell proliferation. BMC Complementary and Alternative Medicine. 2013;13(1):771-13. http://dx.doi. org/10.1186/1472-6882-13-77.

4. Rupande G and Bukaliya R. The Efficacy of Indigenous Knowledge in Scaling up HIV/AIDS Treatment-Practices and Challenges: The Case of Zimbabwe. International Journal of Advanced Research. 2013;1(10):678-90.

5. Mogale MA, Mkhombo HM, Lebelo SL, Shai LJ, Chauke MA and Freitas A. The effects of Clausena anisata (Wild) Hook leaf extracts on selected diabetic related metabolizing enzymes. Journal of Medicinal Plants Research. 2012; 6(25):4200-07.

6. Mukandiwa L, Ahmad A, Eloff JN, Naidoo V. Isolation of seselin from Clausena anisata (Rutaceae) leaves and its effects on the feeding and development of Lucilia cuprinalarvae may explain its use in ethnoveterinary medicine. J Ethno Pharmacol. 2013;150(3):886-91.http://dx.doi.org/10.1016/j.jep.2013. 09.037; PMid:24095830.

7. Afolayan AJ, Lawal IO, Grierson DS. The antibacterial activity of Clausena anisata hook, a South African medicinal Plant. Afr J Tradit Complement Altern Med. 2015;12(1):23-7. http://dx.doi.org/10.4314/ajtcam.v12i1.4.

8. Ojewole JAO. Hypoglycaemic effect of Clausena anisata (Wild) Hook methanolic root extract in rats. Journal of Ethno pharmacology. 2002;81(12):231-7. http:// dx.doi.org/10.1016/S0378-8741(02)00085-5.

9. Venkatesalu $V$ and Senthilkumar A. Phytochemical analysis and antibacterial activity of the essential oil of Clausena anisata (Willd.) Hook f. ex. Benth. International Journal of Integrative Biology. 2009;5(2):116-20.

10. Kenechukwu FC, Mbah CJ, Momoh MA, Chime SA, Umeyor CE and Ogbonna JDN. Pharmacological justification for the ethnomedical use of Clausena anisata root-bark extract in the management of epilepsy. Journal of Applied Pharmaceutical Science. 2012;2(9):036-040. http://dx.doi.org/10.7324/japs.2012.2907.

11. Yineger $H$, Yewhalaw D. Traditional medicinal plant knowledge and use by local healers in Sekoru District, Jimma Zone, Southwestern Ethiopia. J. Ethno biology and Ethno Medicine. 2007;3(1):24. http://dx.doi.org/10.1186/1746-42693-24; PMid:17547765 PMCid:PMC1905946.

12. Maharaj $R$, Maharaj $V$, Newmarch $M$ et al. Evaluation of selected South African ethnomedicinal plants as mosquito repellents against the Anopheles arabiensis mosquito in a rodent model. Malaria Journal. 2010;9(1):301. http://dx.doi. org/10.1186/1475-2875-9-301;PMid:21029442 PMCid:PMC2988038.

13. Mavundza1 EJ, Maharaj R, Chukwujekwu JC, Finnie JF and Staden JV. Screening for adulticidal activity against Anopheles arabiensis in ten plants used as mosquito repellent in South Africa. Malaria Journal. 2014;13(1):173.

14. Baldé AM, Traoré MS, Diallo MSTand Baldé ES. Ethno botanical Survey, antimicrobial and anti complement activities of Guinean medicinal plants traditionally used in the treatment of inflammatory diseases in Conakry and Dubreka. Journal of Plant Sciences. Special Issue: Ethno pharmacological Investigation of Medicinal Plants. 2015;3(1-2):11-9.

15. Miaron JOO, Wahome PG and Mapenay IM. Anthelminthic activity of Withania somnifera L. dunal water extract in sheep. East and Central Afiican Journal of Pharmaceutical Sciences. 2006;8(1):6-9 http://dx.doi.org/10.4314/ecajps. v8i1.9717.

16. Agyare C, Agyepong N, Ossei PPS and Boakye1 YD. Antioxidant and in vivo wound healing activities of Clausena anisata. European Journal of Medicinal Plants. 2015;10(2):1-8. http://dx.doi.org/10.9734/EJMP/2015/19792.

17. Kadiri M, Ojewumi AW and Onatade TN . Indigenous uses and phytochemical contents of plants used in the treatment of menstrual disorders and after- child birth problems in abeokuta south local government area of ogun state, Nigeria. Journal of Drug Delivery and Therapeutics. 2015;5(3):33-42.

18. Pant G, Nayak N and Prasuna RG. Enhancement of antidandruff activity of shampoo by biosynthesized silver nano particles from Solanum trilobatum plant leaf. Appl Nano science. 2012;1-9

19. Blois MS. Antioxidant determinations by the use of a stable free radical. Nature 1958;181:1199-1200. http://dx.doi.org/10.1038/1811199a0.

20. Gella FJ, Gubern G, Vidal R and Canalias F. Determinationof total and pancreatic a-amylase in human serum with 2-chloro-4-nitrophenyl-a-D-maltotrioside as substrate. Clinica Chimica Acta. 1997;259(1):147-60. http://dx.doi.org/10.1016/ S0009-8981(96)06481-9. 
21. Ashok Kumar BS, Lakshman K, Nandeesh $\mathrm{R}$ et al. In vitro alpha-amylase inhibition and in vivo antioxidant potential of Amaranthus spinosus in alloxaninduced oxidative stress in diabetic rats. Saudi Journal of Biological Sciences. 2010;18:1-5.http://dx.doi.org/10.1016/j.sjbs.2010.08.002;PMid:23961097PMCid: PMC3730887.

22. Cirillo VP. Mechanism of glucose transport across the yeast cellmembrane. J Bacteriol; 1962;84(3):485-91. PMid:14021412 PMCid:PMC277903.

23. Bhutkar M, Bhise S. In vitro hypoglycemic effects of Albizzia lebbeck and Mucuna pruriens. Asian Pac J Trop Biomed. 2013;3(11):866-70.http://dx.doi. org/10.1016/S2221-1691(13)60170-7.

24. Ahmed F, Sairam S, Urooj A. In vitro hypoglycemic effects of selected dietary fibre sources. J Food Sci Technol. 2011;48(3): 285-9.http://dx.doi.org/10.1007/ s13197-010-0153-7; PMid:23572748 PMCid:PMC3551159.

25. Gayathri GA and Gayathri M. Preliminary qualitative phytochemical screening and In vitro hypoglycemic potential of Acanthus ilicifolius and Evolvulus emerginatus. International Journal of Pharmacy and Pharmaceutical Sciences. 2014;6(6):362-5.

26. Ou S, Kwok KC, Li Y, Fu L. In vitrostudy of possible role of dietary fiber in lowering postprandial serum glucose. J Agric Food Chem; 2001;49:1026-9. http://dx.doi.org/10.1021/jf000574n; PMid:11262066.

27. Venkataramana M, Premasudha $P$, Abirami M et al. Biological synthesis and characterization of silver nanoparticles using Eclipta alba leaf extract and evaluation of its cytotoxic and antimicrobial potential. Bull. Mater. Sci. 2015;38(4):965-73. http://dx.doi.org/10.1007/s12034-015-0945-5.

28. Mock JJ, Barbic M, Smith DR, Shultz DA and Shultz S. Shape effects in plasmon resonance of individual colloidal silver nano particles J. Chem. Phys. 2002; 116(15):6755-9.http://dx.doi.org/10.1063/1.1462610.

29. Devaraj P, Kumari P, Aarti $C$ and Renganathan A. Synthesis and characterization of silver nano particles using Cannonball leaves and their cytotoxic activity against MCF-7 cell line. Journal of Nanotechnology. 2013;1-6.http://dx.doi. org/10.1155/2013/598328.

30. Swarnalatha L, Rachela C, Ranjan S and Baradwaj P. Evaluation of in vitro anti diabetic activity of Sphaeranthus amaranthoides Silver nano particles. International Journal of Nano materials and Bio structures. 2012;2(3):25-9.

31. Aruna A, Nandhini R, Karthikeyan V et al. Comparative anti-diabetic effect of methanolic extract of insulin plant (Costus Pictus) leaves and its silver nanoparticle. Indo American Journal of Pharmaceutical Research. 2014;4(7):3217-30

32. Radhika S, Kumar SR, Sindhu S, Sagadevan E and Arumugam P. Phytochemical investigation and evaluation of antihyperglycemic potential of Premna corymbosa. Int J Pharm Pharm Sci. 2013;5(4):352-6.

33. Kanchana G, Nirubama K and Rubalakshmi G. Evaluation of free radicals scavenging and glucose uptake by isolated rat hemidiaphragm study of Andrographis echioides an indigenous medicinal Plant. Int.J.Curr.Microbiol. App.Sci.2015;4(6):576-83.

Cite this article : Arsia Tarnam Y, Nargis Begum T, Muhammad llyas MH, Mathew S, Govindaraju A, Qadri I. Green synthesis, Antioxidant Potential and Hypoglycemic Effect of Silver Nanoparticles using Ethanolic Leaf Extract of Clausena anisata (Willd.) Hook. F. Ex Benth. of Rutaceae. Pharmacognosy Journal. 2016;8(6):565-575. 